\title{
ANALISIS BELANJA DAERAH KOTA BENGKULU TAHUN 2014-2017 (TINJAUAN EFISIENSI DAN EFEKTIVITAS)
}

\author{
Miftahul Hasanah ${ }^{1)}$, Merri Anitasari ${ }^{2)}$ \\ ${ }^{1}$ Jurusan Ekonomi Pembangunan Fakultas Ekonomi dan Bisnis Universitas Bengkulu \\ Email: miftahulh403@mail.com \\ ${ }^{2}$ Jurusan Ekonomi Pembangunan Fakultas Ekonomi dan Bisnis Universitas Bengkulu \\ Email: merrianitasari@unib.ac.id
}

\begin{abstract}
The purpose of this study was to determine the level of efficiency and effectiveness of regional government expenditure in Bengkulu city. The analysis tools used to determine the implementation of regional government expenditure that is by using a descriptive elaboration which include; data reduction, data presentation, and drawing conclusions/verification. Meanwhile, to determine the level of effectiveness and efficiency of regional government expenditure, by using the ratio of the efficiency and effectiveness. The results of efficiency analysis of regional government expenditure showed that the average of the calculation of the overall efficiency level formulation is $98 \%$, this indicates that the level of efficiency is still low because the result is more than $80 \%$. This suggests that local government is still wasteful in using the budget. The results of analysis of the effectiveness of government spending showed that the calculation of the effectiveness of regional government expenditure formulation of Bengkulu city in the period year of 2008 to 2017 fluctuate with the average rate of effectiveness of 93\%. This it means that the level of effectiveness of regional government expenditure in the Bengkulu city is already effective, this is indicated from the results of calculations which show figure more than $90 \%$.
\end{abstract}

Keywords: Efficiency and Effectiveness: Regional Finance, Regional Expenditure

\section{PENDAHULUAN}

Otonomi daerah di Indonesia merupakan suatu kebijakan yang diberikan oleh pemerintah pusat kepada pemerintah daerah untuk menjalankan sistem pemerintahannya sendiri sesuai dengan kekhasan yang dimiliki oleh daerahnya. Pemberian otonomi luas kepada daerah diarahkan untuk mempercepat terwujudnya kesejahteraan masyarakat melalui peningkatan pelayanan, pemberdayaan dan peran serta masyarakat. Di samping itu melalui otonomi luas daerah diharapkan mampu meningkatkan daya saing dengan memperhatikan prinsip demokrasi, pemerataan, keadilan, keistimewaan dan kekhususan serta potensi dan keanekaragaman daerah dalam sistem Negara Kesatuan Republik Indonesia.

Anggaran dilaksanakan pada periode satu tahun ke depan, tentunya mengacu kepada anggaran dan realisasi yang dicapai pada tahun sebelumnya yang dipergunakan sebagai tolak ukur pembuatan anggaran berikutnya. Tanpa adanya suatu kejelian dalam menganalisa anggaran yang akan dibuat maka tidak akan didapat realisasi yang sesuai dalam anggaran keuangan pada DPKKAD kota Bengkulu tentunya akan berimbas pada kurang optimalnya hasil pencapaian kinerja.

Tabel 1 Kondisi Keuangan Daerah Kota Bengkulu (Ribu Rupiah) 2014-2017

\begin{tabular}{cccc}
\hline Tahun & Realisasi Pendapatan & Realisasi Belanja & CLR \\
\hline 2014 & $937.898 .451,01$ & $882.511 .866,50$ & $94.09 \%$ \\
2015 & $1.048 .655 .479,99$ & $1.033 .432 .727,07$ & $98.55 \%$ \\
2016 & $1.134 .818 .232,21$ & $1.036 .827 .029,69$ & $91.37 \%$ \\
2017 & $1.128 .046 .885,50$ & 1113702578.90 & $98.73 \%$ \\
\hline
\end{tabular}

Sumber : BPS, Keuangan Daerah Kota Bengkulu Tahun 2014-2017 (data diolah) 
Pembiayaan pembangunan berasal dari dua sumber yakni Anggaran Pendapatan Belanja Negara (APBN) dan Anggaran Pendapatan Belanja Daerah (APBD). Berdasarkan dari laporan realisasi Anggaran Pendapatan Belanja Daerah Kota Bengkulu tahun 2014-2017 menunjukkan bahwa realisasi pendapatan pemerintah kota Bengkulu cenderung mengalami peningkatan akan tetapi pada tahun 2017 mengalami penurunan. Sedangkan jika dilihat dari sisi belanja, struktur belanja pemerintah kota Bengkulu pada tahun 2014 sampai dengan 2017 mengalami peningkatan.

Permasalahan yang terjadi di pemerintahan kota Bengkulu pada pelaksanaan APBD adalah tuntutan agar pemerintah daerah menghabiskan anggaran yang sudah direncanakan untuk tahun bersangkutan selalu memicu pengeluaran/belanja daerah yang terkesan ngasal, yang penting anggaran habis namun tidak peduli terhadap efisiensi, efektivitas dan optimal tidaknya serta manfaat yang sebesar-besarnya bagi masyarakat. Maka tidak aneh, diakhir tahun anggaran makin banyak pekerjaan fisik yang dilaksanakan. Realisasi anggaran pemerintah daerah mencatat hampir setiap tahun anggaran ada dana yang tidak terealisasi di rekening kas daerah yang berakibat hilangnya manfaat belanja, karena dana yang dialokasikan ternyata tidak semua dapat dimanfaatkan oleh pemerintah yang artinya ada dana yang menganggur atau tidak tepat sasaran.

Analisis belanja daerah sangat penting dilakukan untuk mengevaluasi apakah pemerintah daerah telah menggunakan APBD secara ekonomis, efisiensi dan efektivitas. Sejauh mana pemerintah daerah melakukan efisiensi anggaran, menghindari pengeluaran yang tidak perlu dan pengeluaran yang tidak tepat sasaran. Pemerintah tidak perlu lagi berorientasi untuk menghabiskan anggaran yang berkaitan terjadinya pemborosan anggaran melainkan berorientasi pada output dan outcome dari anggaran (Mahmudi, 2010).

Berdasarkan latar belakang masalah di atas, pengendalian keuangan sangat penting dilakukan agar anggaran belanja yang ditetapkan dapat membiayai semua kebutuhan program yang dijalankan serta realisasinya dapat sesuai dengan anggaran yang ditetapkan. Melalui data rekening belanja yang terdapat dalam anggran belanja lembaga/organisasi pemerintah, akan dilihat apakah anggaran yang telah dibuat sudah efisien dan efektif serta dapat berperan sebagai pengendali terhadap pelaksanaan kegiatan pemerintah. Perumusan permasalahan yang hendak dianalisis dalam penelitian ini adalah bagaimana tingkat efisiensi dan efektivitas belanja pemerintah daerah di Kota Bengkulu selama 2008-2017?. Tujuan yang ingin dicapai dalam penelitian ini adalah untuk menganalisis tingkat efisiensi dan efektivitas belanja pemerintah daerah di Kota Bengkulu selama 2008- 2017.

\section{LANDASAN TEORI}

\section{Desentralisasi Fiskal}

Desentralisasi merupakan sebuah instrumen untuk mencapai salah satu tujuan bernegara, yaitu terutama memberikan pelayanan publik yang lebih baik dan menciptakan proses pengambilan keputusan publik yang lebih demokratis. Desentralisasi akan diwujudkan dengan memberikan kewenangan kepada tingkat pemerintahan yang lebih rendah untuk melakukan pembelanjaan, kewenangan untuk memungut pajak (taxing power), terbentuknya dewan yang dipilih oleh rakyat, kepala daerah yang dipilih oleh rakyat, dan adanya bantuan dalam bentuk transfer dari pemerintah pusat (Bird, 2000).

\section{Anggaran Daerah}

Untuk melaksanakan hak dan kewajibannya serta melaksanakan tugas yang dibebankan oleh rakyat, pemerintah harus mempunyai suatu rencana yang matang untuk mencapai suatu tujuan yang dicitacitakan. Rencana-rencana tersebut yang disusun secara matang nantinya akan dipakai sebagai pedoman 
dalam setiap langkah pelaksanaan tugas Negara. Oleh karena itu rencana-rencana pemerintah untuk melaksanakan keuangan Negara perlu dibuat dan rencana tersebut dituangkan dalam bentuk anggaran (Ghozali, 2002).

Pendekatan anggaran kinerja adalah suatu sistem anggaran yang mengutamakan upaya pencapaian hasil kerja (output) dari perencanaan alokasi biaya (input) yang telah ditetapkan (PP. Nomor 105 tahun 2000, pasal 8). Kinerja mencerminkan efisiensi dan efektifitas pelayanan publik dan harus berpihak pada kepentingan publik, yang artinya memaksimumkan penggunaan anggaran untuk memenuhi kebutuhan masyarakat daerah. Anggaran Pendapatan dan Belanja Daerah (APBD) adalah rencana keuangan tahunan pemerintah daerah yang dibahas dan disetujui bersama oleh Pemerintah daerah dan DPRD, dan ditetapkan dengan Peraturan Daerah, jadi APBD merupakan wujud pengelolaan keuangan daerah yang ditetpkan setiap tahun dengan Peraturan Daerah. Struktur keuangan daerah berdasarkan Kepmendagri 29 Tahun 2002 merupakan satu kesatuan yang terdiri dari Pendapatan Daerah, Belanja daerah dan Pembiayaan.

Pendapatan Daerah adalah semua penerimaan daerah dalam periode tahun anggaran tertentu yang menjadi hak daerah dan tidak perlu dibayar kembali oleh daerah. Penerimaan daerah adalah semua penerimaan kas daerah dalam tahun tertentu. Menuru Permendagri No.13/2006 tentang "Pedoman Pengelolaan Keuangan Daerah menyebutkan bahwa Pendapatan Asli Daerah dibagi menurut jenis pendapatan yang terdiri atas:

1) Pajak Daerah

2) Retribusi Daerah

3) Hasil pengelolaan kekayaan daerah yang dipisahkan

4) Lain-lain PAD yang sah.

Di dalam perekonomian, pemerintah telah berperan yang terlihat pada alokasi anggaran khususnya alokasi pengeluaran. Keynes (Todaro, 2006) berpendapat tingkat kegiatan dalam perekonomian ditentukan oleh perbelanjaan agregat. Pada umunya perbelanjaan agregat dalam suatu periode tertentu adalah kurang dari perbelanjaan agregat yang diperlukan untuk mencapai tingkat full employment. Keynes berpendapat sistem pasar bebas tidak akan dapat membuat penyesuaian-penyesuaian yang akan meciptakan full employment. Untuk mencapai kondisi tersebut diperlukan kebijakan pemerintah. Tiga bentuk kebijakan pemerintah yaitu kebijakan fiskal, moneter dan pengawasan langsung. Kebijakan fiskal melalui pengaturan anggaran pengeluaran dan penerimaan pemerintah. Kebijakan moneter dilakukan dengan memengaruhi jumlah uang beredar dan tingkat suku bunga. Pengawasan langsung dilakukan dengan membuat peraturan- peraturan.

\section{Efisiensi Pengelolaan Keuangan}

Efisiensi pengelolaan anggaran daerah adalah rasio yang menunjukkan seberapa besar efisiensi dari suatu pelaksanaan kegiatan/proyek dengan melakukan perbandingan antara output dan input. Pengukuran efisiensi keuangan daerah dapat dilakukan dengan menghitung rasio efisiensi keuangan daerah. Rasio efisiensi adalah rasio yang menggambarkan perbandingan realisasi pengeluaran (belanja) dengan realisasi penerimaan daerah (Halim, 2007).

Rasio Efisiensi $=\frac{\text { Realisasi Belanja }}{\text { Realisasi Pendapatan }} \times 100 \%$

Kriteria untuk mengukur efisiensi pengelolaan keuangan daerah menurut Kepmendagri No. 690.900-327 Tahun 1996 yaitu : lebih dari 100\% tidak efisien; antara 90\%- 100\% kurang efisien; antara 80\% - 90\% cukup efisien; antara 60\% - 80\% efisien; dibawah 60\% sangat efisien. Berdasarkan rumusan tersebut penilaian efisiensi dikatakan sangat efisien apabila hasil 
perhitungan di bawah 60\%. Karena efisiensi di ukur dengan membandingkan keluaran dan masukan,maka perbaikan efisiensi dapat dilakukan dengan cara :

1. Meningkatkan output pada tingkat input yang sama.

2. Meningkatkan output dalam proporsi yang lebih besar daripada proporsi peningkatan input.

3. Menurunkan input pada tingkatan output yang sama

4. Menurunkan input dalam proporsi yang lebih besar daripada proporsi penurunan output.

\section{Efektifitas Pengelolaan Keuangan}

Halim (2008) mengemukakan rasio efektivitas manggambarkan kemampuan Pemerintah Provinsi (Pemprov) dalam merealisasikan anggaran belanja yang direncanakan dibandingkan dengan target yang ditetapkan berdasarkan potensi rill daerah. Dari pengertian tersebut dapat diambil kesimpulan bahwa efektivitas adalah perbandingan antara output (keluaran) dengan tujuan, sehingga untuk mengetahui efektivitas pengelolaan keuangan yaitu dengan membandingkan antara realisasi belanja dengan target belanja.

Rasio Efektivitas $=\frac{\text { Realisasi Belanja }}{\text { Target Belanja }} \times 100 \%$

Kriteria penilaian dan kinerja keuangan dapat diketahui efektif atau tidak menurut Kepmendagri No. 690.900-327 Tahun 1996 dengan memenuhi kriteria sebagai berikut:

1. Hasil perbandingan atau tingkat pencapaian diatas $100 \%$ berarti sangat efektif

2. Hasil pebandingan antara $90 \%-100 \%$ berarti efektif

3. Hasil perbandingan $80 \%-90 \%$ berarti cukup efektif

4. Hasil perbandingan $60 \%-80 \%$ berarti kurang efektif

5. Hasil perbandingan dibawah $60 \%$ berarti tidak efektif

Berdasarkan penelitian yang dilakukan oleh Endah, et al (2014) dengan judul "Analisis Efisiensi dan Efektivitas Serta Kemandirian Pengelolaan Keuangan Daerah di Kabupaten Minahasa Utara". Dalam penelitian ini digunakan analisis rasio efektifitas dan rasio efisiensi untuk melihat sejauh mana pemerintah kabupaten minahasa utara mengelola keuangan yang dimiliki dan mampu meningkatkan perekonomiannya. Penghitungan rasio yang dilakukan menghasilkan angka efisiensi rata-rata diatas 75 persen selama tahun penelitian (2009 - 2013), sementara untuk efektivitas kinerja mencapai angka rata-rata 90 persen per tahunnya.

Selanjutnya, Rondonuwu, et al (2015) Analisis Efisiensi dan Efektivitas Pengelolaan Keuangan Daerah Pada Dinas Pendapatan Daerah Kabupaten Minahasa. Penelitian ini bertujuan untuk menganalisis apakah pendapatan dan belanja daerah di Dinas Pendapatan Daerah Kabupaten Minahasa telah dilaksanakan secara efisien dan efektif. Metode analisis yang digunakan adalah analisis deskriptif. Hasil penelitian berdasarkan Pedoman Penilaian dan Kinerja Keuangan pada Dinas Pendapatan Daerah Kabupaten Minahasa secara keseluruhan, rata-rata tingkat efektivitas pengelolaan keuangan daerah pada Dinas Pendapatan Daerah Kabupaten Minahasa selama tahun anggaran 2010 sampai dengan tahun 2014 dinyatakan sangat efektif. Hal ini menunjukan kinerja pemerintah dalam merealisasikan pendapatan asli daerah berdasarkan potensi riil daerah dalam tahun anggaran 2010 sampai 2014 sudah sangat baik.

Penelitian sebelumnya tentang tingkat efisiensi anggaran dilakukan oleh Christien (2011) pada SKPD Kantor Kecamatan Selat Kapuas Provinsi Kalimantan Tengah Periode 2008 s.d. 2010. Hasil penelitian Christien (2011) menunjukkan bahwa tingkat efisiensi belanja pada SKPD Kecamatan Selat dari tahun 2008 sampai dengan tahun 2010 menunjukkan tren ke arah efisien, karena rasio yang dicapai untuk tahun 2008 sampai dengan 2010 menunjukan bahwa angka rasio yang dicapai semakin kecil dan menggambarkan bahwa SKPD Kecamatan Selat dalam menggunakan anggaran semakin efisien. 
Dalam penelitian ini lebih menitikberatkan pada pembahasan salah satu prinsip keuangan daerah, yaitu melakukan optimalisasi anggaran secara ekonomis, efisiensi dan efektivitas. Ekonomi berkaitan dengan pemilihan dan penggunaan sumber daya dalam jumlah dan kualitas tertentu pada harga yang paling murah. Efisiensi berarti bahwa penggunaan dana masyarakat (public money) tersebut dapat menghasilkan output yang maksimal (berdaya guna). Efektivitas berarti bahwa penggunaan anggaran tersebut harus mencapai target- target atau tujuan kepentingan publik.

Dalam alur penelitian ini, digambarkan paragdima penelitian sebagai berikut :

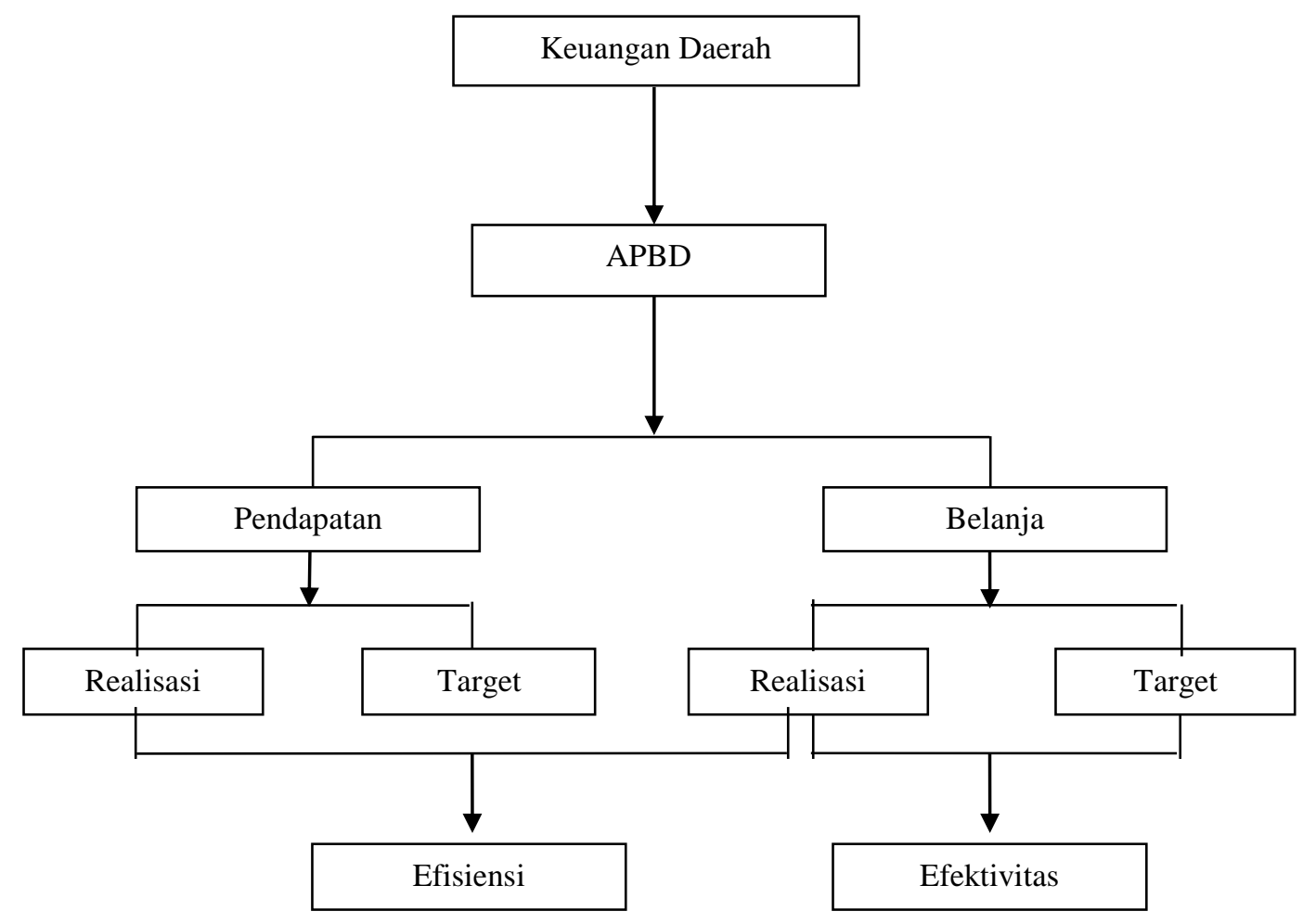

Gambar 1 Kerangka Analisis

\section{METODE PENELITIAN}

Jenis penelitian ini adalah penelitian deskriptif dan/bersifat studi kasus yang dikaji secara kuantitatif. Dalam hal ini dipaparkan posisi fiskal daerah dan juga kondisi keuangan Kota Bengkulu, sedangkan secara kuantitatif dihitung kekuatan efisiensi dan efektifitas Belanja Pemerintah Daerah di Kota Bengkulu. Unit Analisis pada penelitian ini adalah belanja daerah kota Bengkulu tahun 2008 sampai dengan tahun 2017. Adapun Jenis data yang digunakan dalam penelitian adalah data sekunder yang bersifat kuantitatif dari tahun 2008 sampai 2017. Data yang dipergunakan dalam penelitian ini adalah anggaran pendapatan, realisasi pendapatan, anggaran belanja dan realisasi belanja daerah kota Bengkulu. Pengumpulan data dilakukan dengan menghimpun dokumen yang berkaitan dengan masalah penelitian dan berbagai institusi melalui data seri waktu (time series).

Metode analisis yang digunakan untuk menganalisis hasil penelitian ini adalah metode analisis deskriptif yaitu suatu metode pembahasan yang sifatnya menguraikan, menggambarkan, membandingkan dan menerangkansuatu data atau keadaan yang sedemikian rupa sehingga dapat ditarik suatu kesimpulan yang relevan dengan teori. Berikut analisis data yang digunakan : 


\section{Analisis Efisiensi}

Untuk menganalisis tingkat efisiensi dalam pengelolaan keuangan dengan melihat perbandingan antara realisasi dengan anggaran belanja dimana semakin kecil rasio berarti semakin efisien, begitu pula sebaliknya sebagai berikut:

Rasio Efisiensi $=\frac{\text { Realisasi Belanja }}{\text { Realisasi Pendapatan }} \times 100 \%$

Dengan mengetahui perbandingan pengeluaran dan realisasi penerimaan daerah maka tingkat efisiensi pengelolaan keuangan daerah Kota Bengkulu di berikan penilaian dengan menggunakan kriteria penilaian dan kinerja keuangan yang disusun pada Tabel 1.2

Tabel 2 Kriteria Kinerja Keuangan (Efisiensi).

\begin{tabular}{ll}
\hline Presentase kinerja Keuangan & Kriteria \\
\hline $100 \%$ ke atas & Tidak efisien \\
$90 \%-100 \%$ & Kurang efisien \\
$80 \%-90 \%$ & Cukup efisien \\
$60 \%-80 \%$ & Efisien \\
Di bawah dari $60 \%$ & Sangat efisien \\
\hline
\end{tabular}

Sumber: Kepmendagri Tahun 1996 No.690.900.327

\section{Analisis Efektivitas}

Untuk mengetahui efektivitas pengelolaan keuangan yaitu dengan membandingkan antara realisasi belanja dengan target belanja sebagai berikut:

Rasio Efektivitas $=\frac{\text { Realisasi Belanja }}{\text { Target Belanja }} \times 100 \%$

Dalam menganalisis tingkat efektivitas dari sistem pengelolaan keuangan daerah kota Bengkulu maka di perlukan data realisasi belanja dan target belanja. Dengan mengetahui perbandingan hasil target dan realisasi, maka tingkat efektivitas pengelolaan keuangan daerah kota Bengkulu di berikan penilaian dengan menggunakan kriteria penilaian dan kinerja keuangan yang disusun pada

Tabel 3 Kriteria Kinerja Keuangan (Efektifitas)

\begin{tabular}{ll}
\hline Presentase kinerja Keuangan & Kriteria \\
\hline $100 \%$ ke atas & Sangat efektif \\
$90 \%-100 \%$ & Efektif \\
$80 \%-90 \%$ & Cukup efektif \\
$60 \%-80 \%$ & Kurang efektif \\
Di bawah dari $60 \%$ & Tidak efektif
\end{tabular}

Sumber: Kepmendagri Tahun 1996 No.690.900.327 


\section{HASIL DAN PEMBAHASAN}

\section{Deskripsi Target Pendapatan Dan Realisasi Pendapatan Pemerintah Kota Bengkulu.}

Dimana total pendapatan yang ditargetkan Tahun 2008 sebesar Rp. 450,130,260,146.48 terealisasi Rp. 453,141,761,873.98, sedangkan Tahun 2016 ditargetkan Rp 1,230,128,384,270.69 dapat direalisasikan $\mathrm{Rp} 1,134,710,416,731.36$, dan pada Tahun 2017 ditargetkan Rp 1,181,211,907,984.75 dapat terealisasi Rp 1,128,046,885,548.76. Secara keseluruhan total belanja Pemerintahan Kota Bengkulu baik yang ditargetkan maupun yang direalisasikan trennya meningkat dari tahun ke tahun pada Periode 2008 s.d. 2016. Hanya saja pada tahun 2017 terjadi penurunan, kondisi tersebut menunjukkan bahwa mulai terjadi perlambatan ekonomi dikota Bengkulu pada tahun 2017.

Target pendapatan kota Bengkulu pada tahun 2008 sebesar Rp. 450,130,260,146.48 terealisasi sebesar Rp. 453,141,761,873.98. Sedangkan pada tahun 2017 Target pendapatan kota Bengkulu sebesar Rp. 1,181,211,907,984.75 terealisasi sebesar Rp. 1.128.046.885.548,76 ribu rupiah. Hampir setiap tahun anggaran ada dana yang tidak terealisasi di rekening kas daerah yang berakibat hilangnya manfaat belanja, karena dana yang dialokasikan ternyata tidak semua dapat dimanfaatkan oleh pemerintah yang artinya ada dana yang menganggur atau tidak tepat sasaran. dapat dilihat pada

Tabel 4 Realisasi Pendapatan dan Target Pendapatan Kota Bengkulu Tahun 2008-2017.

\begin{tabular}{llll}
\hline Tahun & $\begin{array}{l}\text { Realisasi Pendapatan } \\
\text { (dalam rupiah) }\end{array}$ & $\begin{array}{l}\text { Target Pendapatan } \\
\text { (dalam rupiah) }\end{array}$ & Lebih/ Kurang \\
\hline 2008 & $453,141,761,873.98$ & $450,130,260,146.48$ & $3,011,501,727.50$ \\
2009 & $475,664,056,169.03$ & $491,162,327,128.79$ & $(15,498,270,959.76)$ \\
2010 & $535,671,774,733.62$ & $545,397,764,555.15$ & $(9,725,989,821.53)$ \\
2011 & $611,815,153,447.27$ & $615,877,514,247.10$ & $(4,062,360,799.83)$ \\
2012 & $677,219,227,884.87$ & $679,024,009,266.11$ & $(1,804,781,381.24)$ \\
2013 & $793,506,064,970.03$ & $784,768,051,303.71$ & $8,738,013,666.32$ \\
2014 & $937,898,451,019.95$ & $933,665,413,303.71$ & $4,233,037,716.24$ \\
2015 & $946,911,913,336.56$ & $1,022,977,351,406.00$ & $(76,065,438,069.44)$ \\
2016 & $1,134,710,416,731.36$ & $1,230,128,384,270.69$ & $(95,417,967,539.33)$ \\
2017 & $1,128,046,885,548.76$ & $1,181,211,907,984.75$ & $(53,165,022,435.99)$ \\
\hline
\end{tabular}

Sumber : DPPKAD Kota Bengkulu (data diolah).

Dana perimbangan sebagai dana transfer dari pusat, mempunyai kontribusi terbesar dari total penerimaan daerah yaitu sebesar $80 \%$. Besarnya kontribusi dana perimbangan terhadap total penerimaan daerah mengindikasikan masih lemahnya anggaran daerah kota Bengkulu dalam membiayai penyelenggaraan pemerintahan melalui Pendapatan Asli daerah (PAD) hanya rata-rata dibawah $10 \%$. Hal ini memberikan gambaran bahwa kinerja fiskal penerimaan daerah kota Bengkulu melalui PAD belum menunjukkan hasil yang baik. Dengan kata lain, pembiayaan pembangunan kota Bengkulu sebagian masih bergantung pada pusat.

\section{Deskripsi Target Belanja dan Realisasi Belanja Pemerintahan Kota Bengkulu}

Dimana total belanja yang ditargetkan Tahun 2008 sebesar Rp. 480.574.171.588,67 terealisasi Rp. 439,848,854,619.00, sedangkan Tahun 2009 ditargetkan $\mathrm{Rp}$ 534,398,327,128.79 dapat

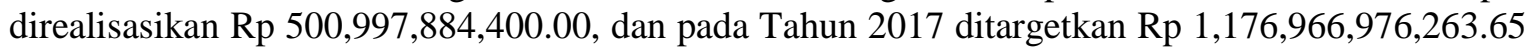
dapat terealisasi Rp 1,113,702,578,948.04. Secara keseluruhan total belanja Pemerintahan Kota Bengkulu baik yang ditargetkan maupun yang direalisasikan trennya meningkat dari tahun ke 
tahun pada Periode 2008 s.d. 2017. Akan tetapi, secara keseluruhan dana yang dianggarkan setiap tahunnya banyak yang tidak terealisasi disebabkan adanya penghematan-penghematan dari program kegiatan yang dilaksanakan dan terdapat beberapa kegiatan yang tidak dapat dilaksanakan. Namun demikian, sebagian besar kegiatan telah dianggarkan kembali pada APBD Tahun Anggaran berikutnya. Dapat dilihat pada Tabel 1.5.

Tabel 5 Target Belanja dan Realisasi Belanja Pemerintahan Kota Bengkulu Tahun 20082017.

\begin{tabular}{llll}
\hline Tahun & $\begin{array}{l}\text { realisasi belanja } \\
\text { (dalam rupiah) }\end{array}$ & $\begin{array}{l}\text { target belanja } \\
\text { (dalam rupiah) }\end{array}$ & lebih/ (kurang) \\
\hline 2008 & $439,848,854,619.00$ & $480,574,171,588.67$ & $(40,725,316,969.67)$ \\
2009 & $500,997,884,400.00$ & $534,398,327,128.79$ & $(33,400,442,728.79)$ \\
2010 & $543,456,354,281.00$ & $570,363,945,292.00$ & $(26,907,591,011.00)$ \\
2011 & $595,218,619,343.00$ & $616,116,485,821.82$ & $(20,897,866,478.82)$ \\
2012 & $642,273,933,972.28$ & $680,584,694,537.20$ & $(38,310,760,564.92)$ \\
2013 & $756,926,896,974.00$ & $796,262,253,484.39$ & $(39,335,356,510.39)$ \\
2014 & $882,511,866,500.50$ & $981,465,993,480.71$ & $(98,954,126,980.21)$ \\
2015 & $1,032,490,311,300.39$ & $1,121,934,462,724.26$ & $(89,444,151,423.87)$ \\
2016 & $1,036,720,514,210.95$ & $1,154,462,784,268.18$ & $(117,742,270,057.23)$ \\
2017 & $1,113,702,578,948.04$ & $1,176,966,976,263.65$ & $(63,264,397,315.61)$ \\
\hline
\end{tabular}

Sumber : DPPKAD Kota Bengkulu (data diolah).

Tingkat Efisiensi dan Efektivitas Belanja Pemerintah Daerah Kota Bengkulu Selama 20082017.

Berdasarkan (tabel 5) hasil penelitian diatas bahwa perkembangan rasio efisiensi belanja pemerintah daerah kota Bengkulu selama tahun 2008-2017 tidak mengalami perubahan yang signifikan yaitu 97\% pada tahun 2008 menjadi 98\% tahun 2017. Artinya pemerintah kota Bengkulu belum/kurang teciptanya tingkat efisiensi belanja sesuai dengan tugas pokok dan fungsi masing- masing SKPD/OPD. Sedangkan berdasarkan hasil analisis efektivitas belanja pemerintah Kota Bengkulu menyatakan bahwa tingak efektivitas berdasarkan perbandingan antara output dan tujuan/target yaitu realisasi belanja dengan target belanja daerah kota Bengkulu sebesar 93,30\% dengan rata-rata selisih $0,34 \%$ artinya belanja pemerintah sudah efektif dalam menggunakan dan mengelola anggaran belanja.

Penelitian tentang kinerja keuangan pada sektor publik dimana indikator yang digunakan adalah tingkat efektivitas adalah yang dilakukan oleh Ronald dan Sarmiyatiningsih (2010) di Kabupaten Kulon Progo. Periode waktu pengukuran kinerja keuangan yang dilakukan cukup lengkap, yaitu sebelum era otonomi daerah (1996-2000), masa-masa peralihan (2001-2002), dan era otonomi daerah diterapkan (2003-2008). Hasil penelitian menunjukkan bahwa tingkat efektivitas belanja Kabupaten Kulon Progo dari tahun 1996 sampai dengan 2008 berkisar antara 80,96\% sampai 98,68\%, artinya Kabupaten Kulon Progo telah melakukan telah melakukan efektivitas anggaran.

Tabel 6 Perbandingan Tingkat Efisiensi dan Efektivitas Belanja Pemerintah Daerah Kota Bengkulu Selama Tahun 2008-2017.

\begin{tabular}{lllcl}
\hline \multirow{2}{*}{ Tahun } & \multicolumn{2}{c}{ Efisiensi } & \multicolumn{2}{c}{ Efektivitas } \\
& $\%$ & Keterangan & $\%$ & Keterangan \\
\hline 2008 & 97 & Kurang efisien & 91.53 & Efektif \\
2009 & 105 & Tidak efisien & 93.75 & Efektif \\
\hline
\end{tabular}




\begin{tabular}{lllll}
\hline \multirow{2}{*}{ Tahun } & \multicolumn{2}{c}{ Efisiensi } & \multicolumn{2}{c}{ Efektivitas } \\
& $\%$ & Keterangan & $\%$ & Keterangan \\
\hline 2010 & 101 & Tidak efisien & 95.28 & Efektif \\
2011 & 97 & Kurang efisien & 96.61 & Efektif \\
2012 & 95 & Kurang efisien & 94.37 & Efektif \\
2013 & 95 & Kurang efisien & 95.06 & Efektif \\
2014 & 94 & Kurang efisien & 89.92 & Cukup efektif \\
2015 & 109 & Tidak efisien & 92.03 & Efektif \\
2016 & 91 & Kurang efisien & 89.8 & Cukup efektif \\
2017 & 99 & Kurang efisien & 92.03 & Efektif \\
rata-rata & 98 & Kurang efisien & 93 & Efektif \\
\hline
\end{tabular}

Sumber : Hasil Penelitian 2019, diolah

\section{Pengelolaan Belanja Pemerintah Daerah Kurang Efisien}

Pada penelitian ini, berdasarkan hasil analisis efisiensi belanja pemerintah Kota Bengkulu menyatakan bahwa tingak efisiensi berdasarkan perbandingan antara output dan inpu yaitu realisasi belanja dengan realisasi pendapatan daerah kota Bengkulu sebesar 98\% (kurang efisien) itu menunjukkan angka yang besar hampir atau bahkan seluruh total pendapatan dihabiskan untuk belanja pemerintah, artinya pemerintah daerah masih boros dalam menggunakan anggarannya.

Jumlah keseluruhan dana APBD baik yang berasal dari PAD maupun dana perimbangan digunakan untuk mewujudkan kesejahteraan masyarakat. Keberhasilan suatu daerah dalam mewujudkan kesejahteraan masyarakat sangat tergantung pada kebijakan masing-masing pemerintah daerah melalui alokasi sumber-sumber pendanaan yang tercermin pada alokasi belanjanya. Perkembangan alokasi belanja pemerintah untuk kota Bengkulu menurut jenis belanja selama lima tahun menunjukkan porsi belanja pegawai masih menempati peringkat tertinggi yaitu rata-rata diatas $50 \%$ dari total belanjanya. Sementara itu porsi belanja barang mencapai $18.8 \%$, belanja modal $21.4 \%$ dan belanja lainnya hanya $1 \%$ (Gambar 4.1).

Gambar 4.1 Perkembangan Rasio Jenis Belanja Terhadap Total Belanja Kota Bengkulu Tahun 2013-2017.

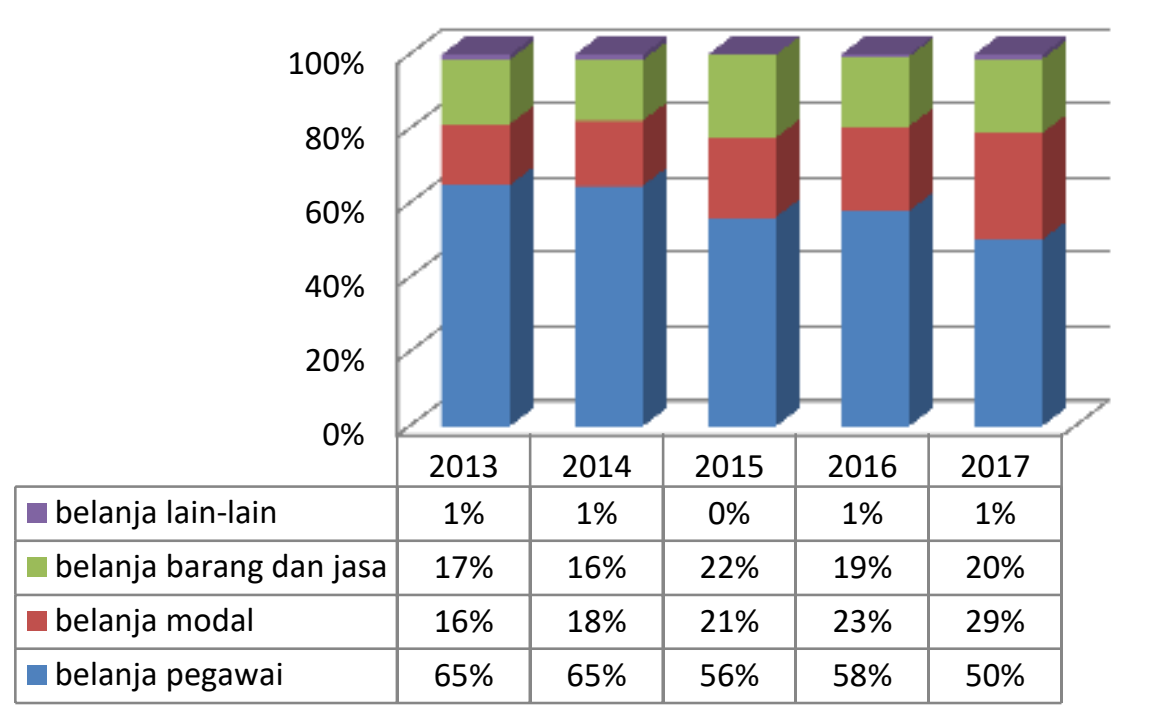

Sumber : Laporan Realisasi Anggaran Pendapatan dan Belanja Daerah Kota Bengkulu Tahun 2013-2017 (data diolah). 
Belanja modal yang diharapkan dapan memacu perkembangan pembangunan ekonomi nampaknya masih menunjukkan proporsi yang masih kecil, walaupun ada indikasi kenaikkan setiap tahun. Padahal jenis belanja modal di era desentralisasi seharusnya mempunyai porsi yang semakin meningkat dari tahun sebelumnya dan paling besar dibandingkan dengan jenis belanja lainnya. Sebab jenis belanja modal ini adalah jenis belanja yang bersifat jangka panjang dan produktif yang digunakan pemerintah untuk membiayai penyediaan barang publik dalam rangka pelaksanaan pembangunan ekonomi yang bertujuan untuk meningkatkan kesejahteraan masyarakat. Namun bila lebih banyak anggaran belanja pegawai, hibah, bantuan sosial dan belanja operasional pemerintah tentulah diragukan besarnya manfaat yang akan dirasakan masyarakat akan anggaran tersebut.

Perencanaan anggaran yang kurang baik jelas berimbas pada pelaksaan anggarannya. Anggaran yang dibuat bukan berdasarkan kebutuhan jelas tidak membuat pelaksanaan harus dilaksanakan secepat mungkin. Anggaran yang dihabiskan belum tentu juga memberikan manfaat pada masyarakat. Hal ini tergantung komposisi anggaran yang dibuat sebelumnya. Masalah anggaran pemerintah tidak sesederhana apakah telah terserap semuanya atau masih banyak yang tersisa.masalah anggaran belanja ini bermula dari perencanaannya dan berlanjut hingga ke pelaksanaannya. Selama tidak ada kemauan dari berbagai pihak, maka anggaran belanja pemerintah tidak dapat dimanfaatkan optimal untuk melayani masyarakat dan membuat rakyat sejahtera. Anggaran hanya menjadi suatu rutinitas yang wajib dilaksanakan tanpa peduli apa yang akan dihasilkan/diberikan pada masyarakat karena tingkat kesejahteraan masyarakat dipengaruhi oleh keputusan yang diambil oleh pemerintah melalui anggaran yang mereka buat, bahwa anggaran pemerintah dibuat untuk membantu menentukan tingkat kebutuhan masyarakat seperti, listrik, air bersih, kualitas kesehatan, pendidikan, dan lain sebagainya agar terjamin secara layak.

\section{KESIMPULAN DAN SARAN}

Berdasarkan hasil penelitian dan pembahasan, dapat diambil kesimpulan sebagai berikut :

1. Pola perkembangan tingkat efisiensi belanja pemerintah daerah di Kota Bengkulu selama tahun 2008 - 2017 cenderung semakin menurun, dari hasil analisis menunjukkan bahwa perhitungan dengan menggunakan formulasi tingkat efisiensi belanja pemerintah daerah Kota Bengkulu dari tahun 2008 sampai 2017 rata-rata adalah sebesar 98\%, artinya tingkat efisiensi masih kurang karena hasilnya lebih dari $80 \%$.

2. Pola perkembangan tingkat efektivitas belanja pemerintah daerah di Kota Bengkulu selama tahun 2008 - 2017 cenderung stabil, dari hasil analisis efektivitas menunjukkan bahwa perhitungan dengan menggunakan formulasi tingkat efektivitas belanja pemerintah Kota Bengkulu tahun 2008 sampai 2017 rata-rata sebesar 93\% per tahun. Dengan demikian berarti tingkat efektivitas belanja pemerintah Kota Bengkulu adalah sudah efektif, karena dari hasil perhitungan menunjukkan angka lebih dari $90 \%$.

3. Berdasarkan persentase komposisi belanja tidak langsung terhadap total belanja setiap tahunnya yang direalisasikan trennya cenderung fluktuasi. Begitu juga dengan persentase komposisi belanja langsung terhadap total belanja setiap tahunnya baik yang dianggarkan maupun yang direalisasikan trennya berfluktuasi. Hampir 60\% realiasasi anggaran digunakan untuk belanja tidak langsung, yaitu untuk belanja pegawai, dan sekitar $40 \%$ dibelanjakan untuk belanja langsung.

4. Pengelolaan belanja pemerintah daerah kota Bengkulu tahun 2008 - 2017 tidak efisien dikarenakan perkembangan alokasi belanja pemerintah untuk kota Bengkulu menurut jenis belanja selama lima tahun menunjukkan porsi belanja pegawai masih menempati peringkat tertinggi yaitu rata-rata diatas $50 \%$ dari total belanjanya. Sementara itu porsi belanja barang mencapai $18.8 \%$, belanja modal $21.4 \%$ dan belanja lainnya hanya $1 \%$ yang artinya banyak dana yang dialokasikan tidak tepat sasaran. 
Berdasarkan uraian kesimpulan dan pembahasan di atas, maka saran yang dapat diberikan untuk meningkatkan efisiensi dan efektivitas belanja pemerintah daerah di kota Bengkulu adalah sebagai berikut:

1. Agar belanja daerah kota Bengkulu bisa lebih efisien, maka Pemerintah daerah dalam hal ini, perlu mengkaji antara sektor yang produktif dengan sektor yang kurang produktif, kemudian pemerintah daerah harus memotong anggaran di sektor yang kurang produktif dan mengalihkannya ke sektor yang lebih produktif.

2. Agar belanja yang dikeluarkan dapat efektif dan efisien, maka hal penting yang harus diketahui oleh manajer publik adalah pemahaman tentang konsep belanja, dengan memahami konsep belanja maka perencanaan dan pengendalian pengeluaran daerah menjadi lebih mudah dilakukan. Agar dalam perencanaan sebisa mungkin merasionalkan belanja sehingga belanja yang dikeluarkan dapat efektif dan efisien. Oleh karena itu formulasi kebijakan umum anggaran belanja daerah diarahkan pada program prioritas, yaitu pendidikan, kesehatan dan pemberdayaan ekonorni masyarakat yang didukung dengan pembangunan infrastruktur wilayah untuk mendorong pertumbuhan sektor-sektor lainnya di Kota Bengkulu.

\section{DAFTAR PUSTAKA}

Astuti, S. Y. 2019. Analisis Efektifitas Pajak Hotel dan Pajak Reklame Serta Kontribusinya Terhadap Pendapatan Asli Daerah Kabupaten. Jurnal Media Komunikasi Ilmu Ekonomi. 24(3): 34 .

Badan Pusat Statistik. 2018 Kota Bengkulu Dalam Angka. https://bengkulukota.bps.go.id/

Basuki. 2007. Pengelolaan Keuangan Daerah. Yogyakarta: Kreasi Wacana.

Bird R, Francois. 2000. Desentralisasi Fiskal di Negara-negara Berkembang. Jakarta: PT Gramedia Pustaka Utama.

Bisma, I., Gde, D., \& Susanto, H. 2010. Evaluasi kinerja keuangan daerah pemerintah Provinsi Nusa Tenggara Barat tahun anggaran 2003-2007. Jurnal Akuntansi. 4 (3): 75-86.

Cicilia, V. S. E., Murni, S., \& Engka, D. 2015. Analisis Efisiensi dan Efektivitas Serta Kemandirian Pengelolaan Keuangan Daerah di Kabupaten Minahasa Utara. Jurnal Pembangunan Ekonomi dan Keuangan Daerah. 17(2): 1-12.

Curtis, P., \& Roupas, T. A. 2009. Health care finance, the performance of public hospitals and financial statement analysis. European Research Studies. 12(4): 199.

Devas, Nick B.B, Anne Booth, Kenneth Davey and Roy Kelly. 2000. Keuangan Pemerintah Daerah di Indonesia. Jakarta: UI-Press.

Fambayun, S. 2015. Analisis Kinerja Keuangan Daerah dan Tingkat Kemandirian Daerah Di Kabupaten Magetan (Tahun Anggaran 2009-2013). Jurnal Akutansi UNESA. 3(2): 1-23.

Halim, Abdul. 2008. Akuntansi Keuangan Daerah, Edisi Revisi. Jakarta: Salemba Empat.

Isworo, W. I. 2007. Akuntabilitas, Responsibilitas, dan Etika dalam Administrasi Publik. Jurnal Ilmu Administrasi dan Organisasi, Bisnis \& Birokrasi. 15(1): 1-23.

Kaunang, C. E. 2016. Analisis Kinerja Pengelolaan Keuangan Daerah Dan Tingkat Kemandirian Daerah Di Era Otonomi Daerah: Studi Pada Kota Manado (Tahun 2010-2014). Jurnal Berkala Ilmiah Efisiensi. 16(2): 335-365.

Kepmendagri No.690.900.327 Tahun 1996.

Mahmudi. 2009. Manajemen Kinerja Sektor Publik, Yogyakarta: UPP STIM YKPN. 
Manopo, N., Rotinsulu, D. C., \& Murni, S. 2015. Analisis Efisiensi dan Efektivitas Pengelolaan Keuangan Daerah Kabupaten Minahasa Tenggara. Jurnal Pembangunan Ekonomi Dan Keuangan Daerah. 17(2): 1-14.

Mardiasmo. 2002. Otonomi dan Manajemen keuangan daerah. Yogyakarta: Andi.

Pangkey, I., \& Pinatik, S. 2016. Analisis Efektivitas Dan Efisiensi Anggaran Belanja Pada Dinas Kebudayaan Dan Pariwisata Provinsi Sulawesi Utara. Jurnal EMBA: Jurnal Riset Ekonomi, Manajemen, Bisnis dan Akuntansi. 3(4): 33-43.

Peraturan Menteri Dalam Negeri Nomor 13 Tahun 2006 tentang Pedoman Pengelolaan Keuangan Daerah. Bandung: Fokusmedia.

Rondonuwu, R. H., Tinangon, J. J., \& Budiarso, N. 2016. Analisis Efisiensi Dan Efektivitas Pengelolaan Keuangan Daerah Pada Dinas Pendapatan Daerah Kabupaten Minahasa. Jurnal EMBA: Jurnal Riset Ekonomi, Manajemen, Bisnis dan Akuntansi. 3(4): 23-32.

Sadono, S. 2006. Ekonomi Pembangunan, Fakultas Ekonomi Universitas Indonesia Bab V. Jakarta: Kencana.

Stiglitz, J.E. 2000. Economics of the Public Sektor. Third Ed. NewYork: W.W. Norton \& Company.

Stroeva, O., Lyapina, I. R., Konobeeva, E. E., \& Konobeeva, O. E. 2015. Effectiveness of Management of Innovative Activities in Regional Socio-Economic Systems. European Research Studies. 18(3): 63.

Suparmoko M.A. 2002. Ekonomi Publik untuk Keuangan dan Pembangunan Daerah, Edisi pertama. Yogyakarta: Andi.

Todaro, Michael P. 1999. Pembangunan Ekonomi di Dunia Ketiga. Jakarta: Erlangga.

Undang-Undang Nomor 33 Tahun 2004 tentang Perimbangan Keuangan Antara Pemerintah Pusat dan Pemerintahan Daerah. Bandung: Fokusmedia.

Wijayanti, S. N. 2017. Hubungan Antara Pusat dan Daerah Dalam Negara Kesatuan Republik Indonesia Berdasarkan Undang-Undang Nomor 23 Tahun 2014. Media Hukum. 23(2):186199. 